\title{
PAISAGENS URBANAS QUASE SEM
}

PAISAGENS ${ }^{1}$

Alberto Pucheu*

Nascido em 1966, Alberto Pucheu é poeta, ensaísta e professor de Teoria Literária da Universidade Federal do Rio de Janeiro (UFRJ). www.albertopucheu.com.b

urbanas quase sem paisagens"

que pode ser vista na íntegra em

<http://www.albertopucheu.com

br/highslide-4.1.13/examples/

paisagensurbanas.html>. 


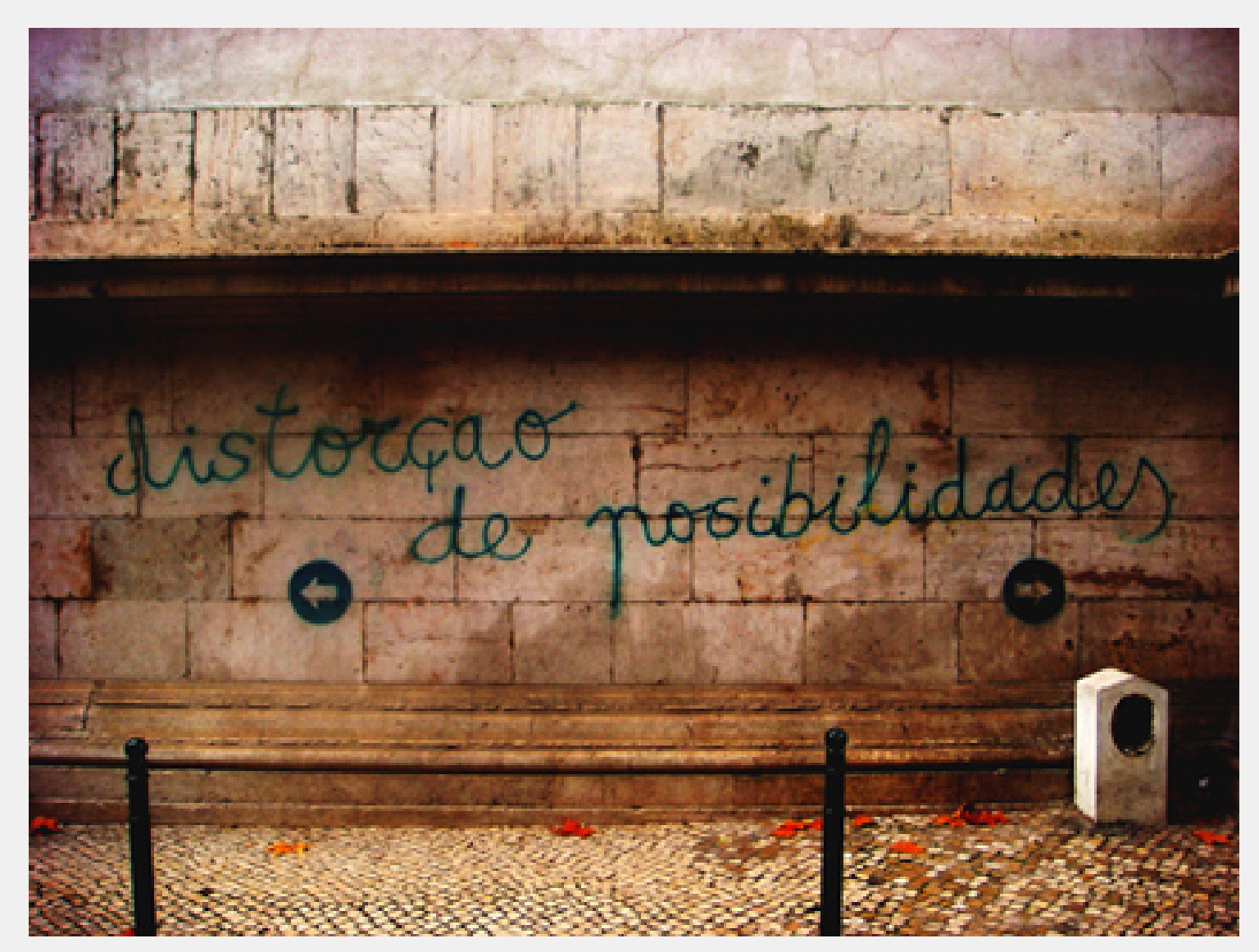












